\title{
Impact of symbolic product design on brand evaluations
}

Article

Accepted Version

Brunner, C. B., Ullrich, S., Jungen, P. and Esch, F.-R. (2016) Impact of symbolic product design on brand evaluations. Journal of Product \& Brand Management, 25 (3). pp. 307-320. ISSN 1061-0421 doi: https://doi.org/10.1108/JPBM-06-20150896 Available at https://centaur.reading.ac.uk/70636/

It is advisable to refer to the publisher's version if you intend to cite from the work. See Guidance on citing.

To link to this article DOI: http://dx.doi.org/10.1108/JPBM-06-2015-0896

Publisher: Emerald

All outputs in CentAUR are protected by Intellectual Property Rights law, including copyright law. Copyright and IPR is retained by the creators or other copyright holders. Terms and conditions for use of this material are defined in the End User Agreement.

\section{www.reading.ac.uk/centaur}

\section{CentAUR}

Central Archive at the University of Reading

Reading's research outputs online 
Impact of symbolic product design on brand evaluations

Christian Boris Brunner

Department of Food Economics and Marketing

University of Reading

Reading

United Kingdom

Sebastian Ullrich

Schmalkalden University of Applied Sciences

Schmalkalden

Germany

Patrik Jungen

Polaris Media

Offenbach

Germany

Franz-Rudolf Esch

EBS Business School

EBS University for Business and Law

Oestrich-Winkel, Greater Frankfurt

Germany

Corresponding author: Christian Boris Brunner

Corresponding Author's Email: Christian.Brunner@csr-brand.com 


\section{Biographical Details:}

Christian Boris Brunner is Manager Market Research at Klöckner Pentaplast Europe GmbH \& Co. KG, Germany, and Visiting Research Fellow at the Agri-Food Economics and Social Sciences Research Division at the University of Reading, UK. Prior to this, he held positions as Senior Lecturer and Lecturer at Newcastle Business School, UK, and at the German University in Cairo (GUC), Egypt. For his research, Christian was awarded the science award from the German Association for Brand Management in 2010 (2nd place) and voted the best 'Early Stage Researcher of the Year 2011' by the German and Austrian Market Research Foundation (2nd place). His research has been published in peer reviewed journals such as Journal of Product and Brand Management, European Advances in Consumer Research and Marketing ZFP Journal of Research and Management as well as in several books. His main research interests include advertising \& branding, especially brand architectures, corporate social responsibility and electronic word of mouth and social media. Christian is the corresponding author and can be contacted at: christian.brunner@csr-brand.com.

Sebastian Ullrich is Professor for Marketing at Schmalkalden University of Applied Sciences. He also is founder and director of Ullrich Consulting, a research oriented brand and communication consultancy located in Germany. He received his $\mathrm{PhD}$ on effects of personalized websites on brand attachment from the University of Giessen, Germany. He was a Lecturer in Marketing at the Academies of Business

Administration and Public Management Giessen. His research interests include online communication, word of mouth, trust and corporate social responsibility. His research has been published in journals like Journal of Product and Brand Management and Marketing ZFP - Journal of Research and Management as well as in several books.

Patrik Jungen is founder and owner of several companies specialized on e-commerce and online marketing services located in Germany. He received his $\mathrm{PhD}$ on the impact of symbolic product design on brand evaluations from the University of Giessen, Germany. He was a Lecturer in Marketing at the Academies of Business Administration and Public Management Giessen. His research was published in several books and journals.

Franz-Rudolf Esch is Professor for Brand Management and Automotive Marketing and Director of the Institute for Brand and Communication Research at EBS Business School, Germany, and Founder of ESCH. The Brand Consultants. Prior to this, he served as professor at Saarland University, University Trier, University Giessen (Germany), University St. Gallen (Switzerland) and University Innsbruck (Austria). His research has been published in journals such as Journal of Consumer Psychology, Psychology \& Marketing, Journal of Product and Brand Management and Marketing ZFP - Journal of Research and Management as well as in several books. His main research interests are brand management, consumer behavior and communication research. 


\section{Structured Abstract:}

Purpose: The purpose of this paper is to investigate the impact of symbolic product information (product design connotations) on consumers' perceived brand evaluations. In an experimental setting we consider as key factors the congruence between design connotation and product category, the level of product involvement as well as brand strength.

Design/methodology/approach: In an experiment of 490 participants, consumers are confronted to different product design connotations. Based on the cognitive process model "SARA" we examined how product design connotations are used as heuristics in the working memory when making brand judgement.

Findings: The results show that product design connotations are used in consumers' information processing as anchor for brand evaluations. This effect is stronger if connotations are incongruent to the product category due to consumers' deeper elaboration process. Furthermore, the impact of design connotations is higher for weak compared to strong brands. When using a congruent product design connotation, a more aesthetic product design can enhance brand connotations as well.

Research limitations/implications: This research supports the cognitive process model "SARA" being an appropriate foundation explaining the effects of symbolic product design. Further research should extend this experiment, using a field study in a more realistic setting and/or a choice situation between different alternative product designs at the point of sale. Furthermore, the consumers' elaboration process should be manipulated differently, e.g. in a Mental Load condition.

Practical implications: Product design connotations are important to enhance brand association networks in the consumers' mind, particularly if the brand is weak.

Marketers should use incongruent symbolic product information to differentiate from competitors who use 'stereotype' product designs.

Originality/value: Research about product design in the marketing discipline is still limited. We analyse the impact of product design connotations on brand evaluations in an experimental setting of 490 respondents in four product categories. The findings support that consumers use product design as heuristics to evaluate brands.

Keywords: Product design, symbolic design, SARA model, brand strength 


\section{Introduction - the importance of product design for brand evaluations}

In the marketplace, brands such as Apple, Boffi, Bose, Mont Blanc and Villeroy $\&$ Boch show that product design can play a key role in favourable consumer response towards a brand (e.g., Landwehr et al., 2012). Although performance, strength or functionality might be the key consumer benefit for products such as computers, kitchen products, audio products, stationery products, bathroom products, and tableware, product design is a (or even the) key driver of those brands' success.

Functional, aesthetic and symbolic dimensions are often considered in research on product design (Bloch, 2011, Homburg et al., 2015). Several studies have demonstrated the impact of the aesthetic component of product design on consumer responses (Veryzer, 1993; Yamamoto and Lambert, 1994). However, a consumer might respond favourably towards the aesthetic dimension of a product but refuse to buy it because it looks "childish" (symbolic dimension) (Creusen and Schoormans, 2005). We assume that this symbolic meaning should have an impact on perceptions of product associations and brand associations. Therefore, the aim of this paper is to examine whether and how symbolic product design influences the way consumers create and perceive a brand and its symbolic associations and which factors moderate these effects. To this end, the paper identifies three research gaps.

Previous studies have explored how product design influences consumers' perceived functionality of a product (Berkowitz, 1987; Kreuzbauer and Malter, 2005). However, as Ravasi and Stigliani (2012) note, little is known about how product design influences product symbolism, especially if there is a discrepancy between the two. For example, users may perceive a smart phone as feminine (symbolic information), and this design might have a high impact on the brand evaluation even though these product design associations do not reflect the product's functional features (e.g., high performance of the mobile phone). Similarly, as in the brand extension literature (Meyers-Levy and Tybout, 1989; Meyers-Levy et al., 1994), we assume that products in a specific product category can have typical or atypical product design (e.g., Clark, 1985). For example, consumers have expectations of what a car should look like and the specific symbolic information it communicates to themselves and others (Landwehr et al., 2011; 2013). This specific symbolic information might activate expectations towards product design in a specific category from "learned" and stored knowledge in consumers' long-term memory (Collins and Loftus, 1975; Lynch and Srull, 1982). Consumers may follow different routes of elaboration regarding the fit to the product category. For example, typical information may be processed on the peripheral route, whereas atypical information may be processed on the central route (Cacioppo and Petty, 1984, Meyers-Levy and Tybout, 1989). 
Following suggestions from Ravasi and Stigliani (2012) for experimental research, the first purpose of this paper is to explore whether consumer responses towards perceived congruent or incongruent symbolic product design differ due to different routes of elaboration processes (central or peripheral routes; Cacioppo and Petty, 1984; Petty et al., 1983).

Second, it is established within the literature that consumers' elaboration processes differ for low- and high-involvement goods due to differently perceived consumer risks (Clarke and Belk, 1978; Kapferer and Laurent, 1986; Petty et al., 1983). If consumers' perceived risk is low, their cognitive effort during a purchase decision is limited. In this case, the impact of peripheral cues (such as symbolic product design) is high (Cacioppo and Petty, 1984; Petty et al., 1983). In contrast, if consumers' involvement is high, the impact of peripheral cues is limited (Cacioppo and Petty, 1984; Petty et al., 1983). Thus, we assume that product involvement moderates between symbolic product design information and consumer responses. Consequently, and in line with Homburg and colleagues' (2015) recommendations for future research, the second purpose of this paper is to explore the impact of symbolic product design on consumers' perceptions of symbolic brand associations for low- and high-involvement products.

Third, consumers hold many associations with strong brands in their long-term memory, whereas the association networks for weak brands are limited (Lynch and Srull, 1982; Wyer and Srull, 1986; Keller, 1993). Thus, a new external cue should have a higher impact on consumers' perceptions of a weak brand. Therefore, the third purpose of this research is to discover whether symbolic product design operates differently for different types of brands depending on consumers' previous knowledge. To the best of our knowledge, the literature has neglected the symbolic meaning that a specific product design activates in a consumer's mind (e.g., the product evokes associations of noblesse) and the impact of these activated associations on weak brands' and strong brands' symbolic associations (e.g., Ravasi and Stigliani. 2012).

In the following section, we provide an overview of the related literature on product design and its symbolic meaning to demonstrate the research gap in consumers' responses towards symbolic product design. As a theoretical foundation, we use the cognitive process model SARA (Selective Activation, Reconstruction, and Anchoring), on which we base consumers' inferences of symbolic product design when judging brands for the hypotheses. After conducting five preliminary studies to develop appropriate stimuli for an experimental approach, we test the assumptions in a main laboratory study with 490 participants. Then, we present and discuss the findings of the experiment and show avenues for future research as well as the managerial implications of the findings. 
Conceptual Framework

Consumer decision making and product design associations

When consumers make purchase decisions at the point of sale, $68 \%$ enter the store without a specific product in mind (Rettie and Brewer, 2000; de Pelsmacker et al., 2006). Even in situations in which consumers make complex decisions between 6-12 alternatives, they make their decision within 6-18 seconds (Pieters and Warlop, 1999). In this short amount of time, consumers are confronted with many product attributes when making judgements, such as price, quality, brand name, assortment, size, colour and product design. In this paper, we focus on product design, particularly symbolic product design, and how it may change consumers' perceptions of a brand.

According to the literature on Gestalt theory (Koffka, 1922; Wertheimer, 1925), human beings perceive an object not from the individual elements of the object but rather from the holistic "gestalt" of all elements as a holistic design. For example, if consumers perceive a new mobile phone, they do not individually evaluate each design element, such as shape, colour or symbolism; rather, they form an overall impression of the holistic design as "all elements working together as a holistic design" (Orth and Malkewitz, 2008). Research has shown that consumers respond more favourably to product design that follows the Gestalt laws of proportion and unity (e.g., Veryzer, 1993).

The concept of product design

Previous research has endeavoured to capture and operationalise product design (for an overview, see Luchs and Swan, 2011 and Homburg et al., 2015). We follow this research stream and argue that product design can communicate functional, aesthetic and symbolic information (Koffka, 1922; Levy, 1959; Lee, 1990; Rafaeli and Vilnai-Yavetz, 2004; Creusen and Schoormans, 2005; Noble and Kumar, 2010; Eisenmann, 2013). Similarly, from a consumer perspective, Bloch (2011) argues as follows: "Design refers to the form characteristics of a product that provide utilitarian, hedonic, and semiotic benefits to the user" (Bloch, 2011, 378). Here, the term "form" is not limited to the tangible characteristics of a product; it also considers elements such as the scent of a car interior or the beat of a music download (Bloch, 2011).

Within the literature, the three-dimensional concept of product design has been supported empirically (Bloch, 2011; Homburg et al., 2015). In this concept, the functional dimension relates to the product's ability to perform its primary purpose (Boztepe, 2007; Bloch, 2011). For example, consumers buy a car to drive from place A 
to place B. Bloch (2011) argues that a design that offers strong functional or utilitarian benefits is reliable, safe and convenient for consumers (Bloch, 2011). The aesthetic dimension focuses on the hedonic function of a product and how consumers perceive its appearance and beauty (Desmet and Hekkert, 2007; Bloch, 2011). This dimension includes consumer experience and engagement with the product as well as the consumer's pleasure while using the product (Desmet and Hekkert, 2007; Chitturi, 2009). For example, consumers perceive hedonic benefits when driving a sports car due to its sinuous lines, its engine and its interior (Bloch, 2011). The symbolic dimension reflects the meaning or sign value that a product design communicates to the consumer and other people (Belk, 1988; McCracken, 1986; Aaker, 1999; Van Rompay et al., 2009, Bloch, 2011).

Previous studies have investigated the effect of one of the three dimensions of product design on consumers' overall product evaluations (e.g., Berkowitz, 1987; Yamamoto \& Lambert, 1994; Bloch, 2011). Research has also explored the interaction effects between dimensions of product design. For example, Creusen and Schoormans (2005) found that respondents selected products depending on their aesthetic dimension. However, when respondents were asked for the reasons for their choice, they based their decision on symbolic associations (Creusen and Schoormans, 2005). For example, a consumer might like the colourful design of a product (aesthetic dimension) but may not intend to buy it because the brand is perceived as "boring" or "childish" (symbolic dimension) (Creusen and Schoormans, 2005). Hence, even though the potential outcomes of the symbolic associations of product design on the perceived aesthetics of products are known, there has been little exploration of the specific elaboration processes of symbolic meaning within the consumer mind set. To the best of our knowledge, the literature has neglected the symbolic meaning that a specific product design activates in the consumer's mind (e.g., the product evokes associations of noblesse) and the impact of these activated associations on the symbolic associations of weak brands and strong brands (e.g., Ravasi and Stigliani. 2012).

The symbolic meaning of product design for consumers

The literature has argued that the symbolic meaning of a product plays an important role in consumers' choices (Hirschman and Holbrook, 1982; Murdoch and Flurscheim, 1983). Based on Gros (1983), we describe symbolic design as a specific product design form that evokes idiosyncratic associations in the mind of the consumer that are learned and stored in long-term memory. Here, we interpret form in a broader way that is not limited to the tangible characteristics of a product (Bloch, 2011). 
The symbolic information of a product design can have several functions (Mono, 1997). First, symbolic information can help consumers to assign a product to a specific category. For example, symbolic information helps consumers to immediately categorise a product into the appropriate product category, to identify the country of origin of a product or to easily recognise the purpose or usage of a product (Mono, 1997). Second, the symbolic information of a product's design can help to identify the specific users of a product (Mono, 1997). Third, symbolic information can be a sign that expresses a consumer's self-image and/or communicates a specific lifestyle to others (Sirgy, 1982; McCracken, 1986; Belk, 1988; Aaker, 1999; Bloch, 2011). For example, consumers can demonstrate their affiliation with a desired social group through particular types of clothes (Simmel, 1957). Here, the concept of "conspicuous consumption" is essential (Veblen, 1953, orig. 1899). In Veblen's view, conspicuous consumption departs from the logical necessity of a good, and calculations of consumption are explainable by the use value of commodities. This type of consumption is a functional ceremonial form linked to status and honour. Hence, some goods are consumed exclusively because of their potential to communicate a specific social status to the public (Veblen, 1953, orig. 1899). Due to their need for identity, consumers act as communicators through their consumption behaviour (Campbell, 1995; Gabriel \& Lang, 1995; Aldridge, 2009). Consumption can be seen as an exchange of symbols between consumers who attempt to convey messages to one another about their lifestyles and identities (Campbell, 1995; Sassatelli, 2007; Aldridge, 2009). The purpose of such behaviour is to create and maintain a (desired) self-image in public (Sirgy, 1982; Schlenker \& Leary, 1985; Schlenker \& Weigold, 1989; 1992). Products and services from a specific brand (that have a specific brand image that others know) are a medium for communicating and maintaining the consumer's selfimage.

O'Cass and Frost (2002) show that congruence between a consumer's selfimage and the brand image supports the perceived status of the brand. In their research on the effects of non-product-related brand associations on status-oriented consumption, they further demonstrate that symbolic characteristics are a strong cause of status and conspicuous consumption (O'Cass and Frost, 2002). For example, consumers might prefer to drive a Jaguar or Maserati to express their unique selfimage and to communicate to others an exclusive and extraordinary lifestyle.

Park and colleagues (1986) present a normative framework to manage brand images strategically. They argue that consumer needs can be differentiated into functional needs, symbolic needs and experiential needs. They regard a mixture of benefits as possible, but they recommend focusing on only one (Park et al., 1986). Findings from Bhat and Reddy (1998) suggest that symbolism and functionality are 
distinct concepts in the brand context. However, consumers also accept brands with both symbolic and functional appeal, such as Nike, which satisfies consumer needs on both levels (Bhat and Reddy, 1998).

Associations in consumers' minds are triggered by previous knowledge that is learned during the consumer's socialisation process (e.g., cultural meanings or symbolic meanings in society, family and peer groups). Without this "learned" knowledge in society, family and peer groups, it is impossible to use a specific symbolic design to express one's self-image through consumption and/or to communicate a specific lifestyle to others (Veblen, 1953, orig. 1899; Simmel, 1957; Campbell, 1995). Therefore, symbolic design has a positive impact on consumers' perceptions of the brand itself (Schmitt and Simonson, 1997). More specifically, we assume that symbolic design may change consumers' associations with a brand (brand associations).

\section{The cognitive process model SARA}

Human beings store information from previous experiences in their long-term memory, the capacity of which is unlimited (Atkinson and Shiffrin, 1968). According to Pohl and colleagues (2003), the SARA (Selective Activation, Reconstruction, and Anchoring) long-term memory model includes a set of images (Pohl and Eisenhauer, 1997; Pohl et al., 2000, 2003). These images are organised according to their similarity and with regard to processes of forgetting. In the so-called working memory, perceived and retrieved information cues are processed to make a judgement (Pohl et al., 2003). The capacity of this memory is limited to a few units of information (Miller, 1956; Cowan, 2001).

The SARA model is based on and partly extended from the associative memory model SAM (Search of Associative Memory) (Raaijmakers and Shiffrin, 1980; Shiffrin and Raaijmakers, 1992). It follows the basic idea that sets of images from long-term memory can be activated and recalled by retrieval cues that are currently active in working memory. Whether they are activated depends on the power of an external or internal cue. For example, a product design (external cue) might activate the existing image of "nobility" in the long-term memory of the consumer. If this activation is strong enough, the image might be considered during the decision-making process in the working memory. The presence of the activated image from the long-term memory in cognitive processes from the working memory might lead to anchoring effects (Pohl et al., 2003). 
Impact of product design on brand associations

Based on the SARA model, we assume that a symbolic product design association (as an external cue) might activate specific consumer product design images in the long-term memory (e.g., a product design evokes associations such as "noble"). These images are incorporated into the consumer's brand judgement process as a heuristic in the working memory and may bias the final outcome concerning the brand's evaluation or associations towards it.

H1: $\quad$ Symbolic product design has a positive impact on consumers' brand associations in the direction of the symbolic design.

The importance of product category congruence and consumer involvement for product design associations

We assume that product categories can have typical or atypical product design features (e.g., Landwehr et al., 2011; 2013). For example, consumers have learned how a typical product design of a car looks like (e.g. Rosch, 1975; Mervis and Rosch, 1981). Therefore, they have expectations how a car "should look like" (Collins and Loftus, 1975; Lynch and Srull, 1982). If they see a new product with a specific product design (and symbolic meaning), they match this design with their existing knowledge.

We consider two effects for the second hypothesis: the level of elaboration and the activated images "competing" in the working memory. (1) If the symbolic product design is incongruent with the typical product design schema, consumers cannot easily integrate incongruent information into existing schemas. They perceive a state of cognitive dissonance (Festinger, 1957). Consequently, their effort to include and process this incongruent information in the working memory is greater when compared to a situation in which symbolic design is congruent (Meyers-Levy and Tybout, 1989; Meyers-Levy et al., 1994). Because of the gained importance of the incongruent product design, consumers may now consider it a central cue and follow the central route of elaboration. (2) Following the SARA model, few images in the long-term memory are activated in this process because the previous knowledge of the incongruent design is limited. Hence, few images "compete" with each other (Meyvis and Janiszewski, 2004; Lynch Jr., 2006) for consideration in the judgement process under high elaboration efforts. Here, the incongruent product design may act as a retrieval cue and lead the memory search (Pohl, 2003). This may cause an anchoring effect or hindsight bias and strengthen the impact of the incongruent product design.

Contrary to this, we expect that in the case of a typical product design (congruent information), cognitive dissonance does not occur and the product design 
information is processed on the peripheral route. As congruent product design matches previous knowledge structures, a large number of images are activated for consideration in the working memory. However, in this condition of low elaboration several images compete in the working memory. Therefore, the effect of each image on the total outcome is limited.

Comparing the effects, we assume that incongruent symbolic product design should have a greater impact on the final outcome compared to a congruent product design - due to (1) fewer images competing to be considered and (2) a higher level of elaboration.

H2: The impact of symbolic design on symbolic brand associations is higher when the symbolic design is incongruent with the product category than when it is congruent.

The importance of congruence between product design associations and product category

Consumers perceive a lower risk when they buy low-involvement products compared with high-involvement products (Clarke and Belk, 1978; Kapferer and Laurent, 1986). If the risk is lower, consumers' cognitive effort during the purchasing decision should be lower. According to the elaboration likelihood model, if consumers' cognitive effort is high (central route of elaboration), the impact of peripheral information on the decision outcome is limited (Cacioppo and Petty, 1984; Petty et al., 1983). However, if cognitive effort is low, the impact of peripheral cues is higher.

Similarly, we assume that if consumers follow the peripheral route of elaboration (as is the case for low-involvement products), peripheral cues such as symbolic design should play a more significant role compared with high-involvement products (Cacioppo and Petty, 1984; Petty et al., 1983).

H3: The impact of symbolic design on symbolic brand associations is greater for low-involvement products than for high-involvement products.

The importance of brand strength for product design associations

According to Keller (1993), customer-based brand equity can be described as the impact of the customer's brand knowledge on his response towards a specific brand. Such brand knowledge consists of two components: brand awareness and brand image (Keller, 1993). Whereas the former defines a consumer's brand recall or recognition, the latter describes a network of associations the customer has in mind 
about the brand (Low and Lamb Jr, 2000; John et al., 2006). These associations can include attitudes about the brand and benefits when using the brand's products as well as product-related and non-product-related attributes (Keller, 1993).

According to the SARA model, these (brand) associations are stored as images in the consumer's long-term memory. In the case of a strong brand, an external cue (such as symbolic design) might activate several images in the long-term memory. These images might compete with each other (Meyvis and Janiszewski, 2004; Lynch Jr., 2006) for consideration in the brand judgement process in the working memory. Hence, the impact of each image on the final decision outcome should be limited (as several images are activated at the same time and are "competing"). In contrast, in the case of a weak brand, the brand knowledge in the long-term memory is limited, meaning that only a few images are stored for the brand. If an external cue activates the brand knowledge in the long-term memory, only a few images "compete" for consideration in the brand judgement process in the working memory. Hence, the impact of each single image in the elaboration process should have a higher impact on the brand evaluation outcome in the working memory. Therefore, we assume that the impact of symbolic design is stronger in the case of a weak brand (as fewer images are activated). Consequently, the heuristic impact of each image should be higher on the consumer's brand judgement process in the working memory.

H4: $\quad$ The impact of symbolic design on symbolic brand associations is higher for weak brands compared to strong brands.

\section{Moderating role of aesthetics in the judgement process}

It has been shown that consumers have a higher acceptance of products with an aesthetic design (Veryzer, 1993; Bloch, 1995). Previous research has shown that aesthetics can increase a consumer's overall product evaluation (Yamamoto and Lambert, 1994). Surprisingly, even in situations in which aesthetic design seems to be irrelevant, it has a positive effect on the overall judgement of that product (Raghubir and Greenleaf, 2006; Madzharov and Block, 2010; Townsend and Shu, 2010). However, other findings show that being less aesthetic could be advantageous (Hoeg et al., 2010). For example, consumers may expect vacuum cleaners from Dyson to be less attractive but superior in performance (Hoeg et al., 2010). To the best of our knowledge, previous research has rarely examined the interaction between the dimension of product aesthetics and product associations.

We follow the research stream that demonstrates the positive effects of product design aesthetics on overall product evaluation (Raghubir and Greenleaf, 2006; Madzharov and Block, 2010; Townsend and Shu, 2010). Consequently, we assume 
that if consumers perceive the product design as more aesthetic, this leads to a higher impact of symbolic design on brand associations.

H5: $\quad$ The impact of symbolic design on symbolic brand associations is higher if consumers perceive the product design as more aesthetic.

\section{Research methodology}

Research design

In the following section, we test the impact of symbolic product design on brand associations by considering three key factors that might interfere with this relationship: the congruence between symbolic product design and product category, product involvement and brand strength. The experimental settings of our main study consist of a 2 (symbolic design: congruent/incongruent with product category) x 2 (product category: high/low involvement) x 2 (brand strength: strong/weak) between-subject factorial design.

To develop the different experimental treatments of the main study, several preliminary studies were needed. Altogether, the research process included five preliminary studies and one main experiment (Appendix 1). Participants for the entire research process were recruited at a large European university and were similar for all of the studies of this paper (average age: $23,50 \%$ female). All constructs of this paper were measured with 7-point scales (ratings from 1 to 7 ). The development of constructs and their measurements are described in the following section.

\section{Preliminary studies and manipulation checks}

Identification of high- and low-involvement product categories

In a first preliminary study, we asked participants $(N=150)$ about their knowledge of 15 different product categories (e.g., TVs, washing machines and printers). To select two low-involvement (toasters and kettles) and two highinvolvement (digital cameras and mobile phones) product categories, we used Kapferer and Laurent's (1986) product category involvement scale. This scale considers five dimensions of involvement, each measured with two items. Based on Kapferer and Laurent (1986), these dimensions included interest (e.g., "Please indicate how interested you are in (name of product category)"), pleasure (e.g., "It is a pleasure for me to buy (name of product category)"), sign value (e.g., "If someone buys products from (name of product category), this says a lot about the person him-/herself"), risk importance (e.g., "Please indicate your perceived importance of potential negative 
consequences when making a poor choice in the product category (name of product category") and risk probability ("How likely it is that you will make a poor choice when buying (name of product category)?") (anchors for all of the items: "strongly disagree" and "strongly agree"; Cronbach's $\alpha$ for each dimension: $\alpha>.7$ ). For the preparation of the next preliminary study we asked participants to state all brands that came to their mind in the product category.

Identification of strong and weak brands

In a second preliminary study $(\mathrm{N}=4 \times 30)$, we determined a strong brand and a weak brand for each of the product categories based on Keller's (1993) dimensions of brand knowledge (brand awareness and brand image). We used the three brands mentioned most often and the three brands stated most rarely in the previous study as the range of brands to be tested. Brands differed in the percentage of brand recall $(p<.01)$. More importantly, brands were different regarding brand attitudes $(p<.01$; based on Mitchell and Olson, 1981, 323; "The brand [name of the brand] is bad/good", "The brand [name of the brand] is unpleasant/pleasant" and "The brand [name of the brand] offers poor quality/high quality").

\section{Development of a scale with congruent and incongruent associations}

For our experiment, we chose two different types of associations based on expert interviews. One type of association was incongruent with the selected product categories ("feminine"), and the other type was congruent with the selected product categories ("noble"). To test these associations, a scale was developed (similar to the semantic differential from Osgood et al., 1957).

In a preliminary study, first, the participants $(\mathrm{N}=30)$ were asked to list all adjectives that came into their minds for the words "feminine" or "noble", separately. Altogether, the subjects stated 163 adjectives for "feminine" and 157 adjectives for "noble". To highlight the importance of the order of the adjectives, the adjectives that were mentioned first were assigned five points each, the adjectives that were mentioned second were allocated four points each, and so on. Associations mentioned sixth or later did not receive any points. Finally, the four adjectives that received the highest scores for the associations "feminine" and "noble" were included in the associations scale. In addition, thirteen other items were added to the final association scale to cover the objective of the study (Appendix 2). 
Development of product design stimuli for the treatments in the main study

For each of the four product categories, the "feminine" and "noble" stimuli were professionally designed by strictly following concrete guidelines. In this process, associations with "feminine" or "noble" were considered with regard to product materials, shapes, colours, signs and surfaces. Additionally, two default products were created for each product category. These products were included in the study design to examine the specific symbolic design of "feminine" or "noble" compared with product designs that did not communicate specific symbolic meanings (Appendix 3 ).

Preliminary study of product design stimuli for the treatments in the main study

The stimuli for each product category were presented to respondents in a computer-assisted 3D animation for 30 seconds to ensure that the symbolic design "noble" was perceived as noble by the respondents $(N=120$, similarly for the symbolic design "feminine") $(p<.001$, Appendix 3$)$.

In another preliminary study, we asked subjects to rate the congruence between the symbolic design (either "noble" or "feminine") of each product category using Lee's (1995) scale to measure schema congruity ("How typical is this product for the [name of product category] (very atypical-very typical)?"; "How similar is this product to other products in the [name of product category] (very different-very similar)?" and "How likely is it that you would find such a product in a [name of product category] store (very unlikely-very likely)?"; Cronbach's $\alpha>.7$ ). The findings indicated that the "feminine" association was perceived as incongruent with each product category, whereas the symbolic design "noble" was perceived as congruent $(N=120$; $\mathrm{p}<.001)$.

Main study: Data collection, procedure and measurement

In the main study, 490 participants were randomly assigned to one of the experimental groups. We asked respondents in each of the groups to evaluate the brand with regard to their attitudes (similar to the second preliminary study) and with regard to the brand associations (using the association scale developed in the preliminary study). Then, we showed an unmarked product that was developed in the preliminary studies. We asked our respondents to rate specific associations and to rate them together with their perceived aesthetics (based on Hirschman, 1986: five adjective pairs: attractive/not attractive, desirable/not desirable, arousing/not arousing, beautiful/not beautiful, and makes me like this product/does not make me like this product). After a filler task, we presented the same product again to our subjects, now marked with the brand name. Respondents rated their brand attitude, specific 
adjective pairs and the product aesthetic again. Then, respondents were asked to state brands of the product category and to answer demographic questions.

\section{Results}

The purpose of this paper was to investigate the impact of symbolic design on brand associations. To calculate the product design effects across different product categories and different brands, we used global distances (GD, the root of the summarised squared single items distances) between the presented stimuli.

(Please include Table_1 about here)

The first hypothesis postulated the influence of symbolic design on the evaluation of the symbolic brand associations in the direction of the symbolic design. In 15 out of 16 cases, the global distances were smaller for the relation between the unmarked product and the marked product (GD2) compared with the difference between the unmarked product and the brand (GD1). In one case, the distance was similar (see Table 1 and Appendix 4). One-sample t-test results showed that participants did not evaluate the brand after the treatment based on the prior brand association only or on the symbolic design only $(p<.05)$. Rather, they used the symbolic design (both the associations "feminine" and "noble") as an anchor for the brand evaluations in all but one of the 16 groups.

Further, we calculated the quotient of GD1 through GD3 for each of the datasets. If GD1 equalled GD3, the evaluations of the symbolic associations of the marked product and the symbolic design would be equal. In this case, the quotient would be 1 . If the evaluations of the symbolic associations of the unmarked product and the marked product were equal, GD1 would be 0; consequently, the quotient would be 0 . Therefore, in normal cases, quotient values should be positive, which we defined as a prerequisite for respondents to be considered in the findings.

It is important to mention that the quotient was negative in the case of 35 respondents in the total sample $(\mathrm{N}=490)$. A reasonable explanation for this pattern is contrast effects (Herr et al., 1983; Strack and Mussweiler, 1997) that might bias the findings. To avoid any bias in our results, we excluded these respondents from further analysis (13 cases of low-involvement and 22 cases of high-involvement products). The higher amount of contrast effects for high-involvement goods shows that the transfer of peripheral associations is more difficult to undertake compared to low- 
involvement products (Cacioppo and Petty, 1984). When focussing on the product design associations of these potentially biased respondents, there were more contrast effects in the case of the feminine product design $(\mathrm{N}=24)$ compared to the noble product design ( $\mathrm{N}=11)$. This finding is consistent with Strack and Mussweiler's (1997) finding that incongruent information causes higher contrast effects than congruent information does.

In a test of the first hypothesis, the results of one-sided t-tests showed that participants shifted the brand significantly to the direction of the symbolic design (GD1 vs. GD3; $p<.05$; Appendix 4), which supports H1.

With regard to the congruity between symbolic design and each product category, we again analysed the quotients of GD 1 through GD 2 and found a higher share of transferred associations for the incongruent symbolic design $(\mu=.7658)$ compared with the congruent symbolic design ( $\mu=.6996 ; p<.01$; Appendix 4$)$. The incongruent association "feminine" was adjusted more than the congruent association "noble", which supports $\mathrm{H} 2$.

Further, we tested the influences of the brand strength, the product category involvement and the control variable product aesthetics in an overall model. The results of a univariate analysis of variance showed significant influences of brand strength $\left(F_{1,368}=6.655, p<.01\right)$ and product category involvement $\left(F_{1,368}=4.561, p<.05\right)$. The product aesthetic factor fell short of significance $\left(F_{1,368}=3.698, p=.055\right)$.

Then, we used two separate models, one in which we focussed on the impact of the symbolic design "feminine" (incongruent situation) and one in which we examined the effects of the symbolic design "noble" (congruent situation).

In the case of incongruence between the symbolic design and the product category (association "feminine"), the results of an univariate analysis of variance demonstrated significant influences of product category involvement $\left(F_{1,190}=8.102\right.$, $p<.05)$, but not with regard to brand strength $\left(F_{1,190}=0.157, p>.05\right)$ or product aesthetics $\left(F_{1,190}=1.716, p>.05\right)$. Hence, for incongruent symbolic designs, $\mathrm{H} 3$ and $\mathrm{H} 4$ were supported, but $\mathrm{H} 5$ was not.

In the case of congruence between the symbolic design and product category (association "noble"), the findings were different. Although the product category involvement was not significant $\left(F_{1,178}=.169, p>.05\right)$, brand strength $\left(F_{1,178}=6.667\right.$, $p<.05)$ and product aesthetics $F_{1,178}=4.303, p<.05$ ) had significant impacts on brand associations. Therefore, for congruent symbolic design, $\mathrm{H} 3$ must be rejected, whereas $\mathrm{H} 4$ and $\mathrm{H} 5$ are supported. 


\section{Discussion and implications}

\section{Theoretical implications}

The findings demonstrate that symbolic product design has a significant impact on consumers' brand evaluations. With regard to our theoretical contribution, we support the SARA model in our findings. Symbolic product design acts as an external cue to activate images such as "feminine" in the long-term memory. These images are incorporated into the brand judgement process in the working memory. In this elaboration process, the symbolic design is used as anchor in the elaboration process to form brand associations. Hence, the SARA model is an appropriate theoretical foundation for explaining the impact of symbolic product design when consumers judge brands.

Within the SARA model the number of images that are activated through an external cue are considered: If more images are activated, they "compete" in the working memory. However, the direction or value between existing consumer knowledge and perceived object needs further consideration. The findings show that the direction is important as an incongruent symbolic product design leads to a deeper elaboration process. Therefore the outcome of both, the number of images considered in the working memory and the level of elaboration, have to be taken into account. This means that one outstanding cue which is incongruent to consumers' expectations with a symbolic product design (evoking high activation and attention of the consumer) can have a much greater effect (anchoring effect) than congruent cues.

Product design can have several functions: helping consumers to categorise a product, to identify a specific user of a product and/or to express their self-image and lifestyle to others (communication function). We assume that particularly the last mentioned function of product meaning is essential. It might be a pre-requisite that consumers are still able to assign a symbolic product design to existing knowledge structures, but more importantly less "usual" symbolic information seems to be key. Even though this needs further exploration in further studies, we assume that the need for identity and uniqueness of consumers is more important than the need for affiliation to a specific group.

Finally, the findings demonstrated mixed results regarding product aesthetics. In the case of incongruent symbolic design, a more aesthetic product design has no significant positive effect on brand evaluations. This finding supports our key finding that outstanding, "unexpected" symbolic product information is important for consumers and their self-image. Only in the case of congruent ("stereotypical") design we found positive effects of product aesthetics, which is in line with previous findings (Veryzer, 
1993; Yamamoto and Lambert, 1994). Here, product aesthetics clearly support the impact of symbolic product design and influence consumers' brand evaluations.

\section{Practical implications}

The results indicate that brand managers need to consider symbolic product design to enhance brand evaluations. Perhaps surprisingly, the impact of design associations is particularly strong when symbolic product design is incongruent with the product category. This means that a brand can capture consumers' attention, particularly if the brand differs from "stereotypical" symbolic product design expectations. However, such differentiation through new and extraordinary symbolic design must be implemented carefully because consumers need to first identify the product in a specific category (Mervis and Rosch, 1981), and unexpected designs may evoke contrast effects (Herr, Sherman and Fazio, 1983). For example, consumers still need to categorise a product "as a car", but then the symbolic design can communicate atypical symbolic product information that will trigger the consumer's attention. In the last century, most laptop computers featured a functional design to enhance efficient working conditions. Laptop computers must be robust and ergonomic (e.g., Dell or HP). Furthermore, one might have thought that consumers would focus on the functionality and would not be willing to pay more for symbolic features, such as product design. Therefore, an elegant symbolic design was rather incongruent with the product category. Nevertheless, Apple's elegantly designed MacBooks proved to be successful in the marketplace and revealed the need for elegant, symbolically designed laptops.

It is essential for marketers to develop incongruent symbolic product information that differs from "stereotypical" consumer expectations. If managers can successfully develop such a symbolic design, the benefit to consumers is high. On the contrary, if managers have no possibility for establishing incongruent symbolic communication with their products, they can increase consumer benefits through more aesthetic product design.

\section{Limitations and avenues for future research}

Research in the field of symbolic product design in the branding area is still limited. This experimental study focussed on two associations in four product categories with eight brands. Future research should include additional control groups and seek further findings in other product categories and brands to achieve greater generalisability. 
This study used an experiment to generalise the theoretical effects of variables. Although this approach enabled us to ensure high internal validity, the external validity is limited. Thus, future research should enrich our findings through a field study.

With regard to the level of congruence between symbolic product design associations and product category, we considered only two levels: congruence and incongruence. One could argue that this approach limits the findings as three levels of congruence can be theoretically considered: high congruence, moderate incongruence and high incongruence (e.g., Mandler, 1982). However, high incongruence seemed to be unrealistic in our study. For example, it is unrealistic that a company would design a mobile phone to evoke associations such as "cheap". Therefore, we neglected this level of congruence.

Furthermore, in the experimental setting, all respondents were exposed to the stimuli in a high-involvement situation. Usually, consumers process information within a few seconds at the point of sale. Although we differentiated between high- and lowinvolvement products, future research needs to consider scenarios in which the elaboration process is manipulated differently. Therefore, in future research, consumers might be confronted with stimuli under a mental load, ensuring that the respondents' cognitive resources are limited in this condition. In addition, future studies could consider a choice scenario in which consumers must make a purchase decision between alternative products with different levels of symbolic information and other product design dimensions.

Finally, using a specific brand's product and/or services communicates a desired lifestyle and identity (Campbell, 1995). The prerequisite is that the receiver of the symbolic message understands the meaning that the sender intends to communicate. All participants in the communication process need to have a similar understanding of the signs and meanings, which is usually the case in the same culture. However, when communicating internationally, the meaning of a specific symbolic product design might be understood differently. Research has shown that, for example, consumers in developing countries have different perceptions and behavioural drivers for preferring global brands (e.g., as a status symbol) compared with consumers in Western countries (Alden et al. 1999; Batra et al. 2000; Bhardwaj et al., 2011). Future research should explore whether and how similar product design meanings are perceived differently between different cultures and the symbolic meaning of brands and their products and services. 


\section{References}

Aaker, J.L. (1999), "The Malleable Self: The Role of Self-Expression in Persuasion", Journal of Marketing Research, Vol. 36 No. 1, pp. 45-57.

Alden, D.L., Steenkamp, J.-B.E.M. and Batra, R. (1999), "Brand positioning through advertising in Asia, North America, and Europe: the role of global consumer culture", Journal of Marketing, Vol. 63 No. 1, pp. 75-87.

Aldridge, A. (2009), Consumption. Cambridge: Polity Press.

Atkinson, R.C., and Shiffrin, R.M. (1968), "Human memory: A proposed system and its control processes", in Spence, K.W. and Spence, J.T. (Eds.), The psychology of learning and motivation (Vol. 2), Academic Press, New York, pp. 89-195.

Batra, R., Ramaswamy, V., Alden, D.L., Steenkamp, J.-B.E.M. and Ramachander, S. (2000), "Effects of brand local/nonlocal origin on consumer attitudes in developing countries", Journal of Consumer Psychology, Vol. 9 No. 2, pp. 83-95.

Berkowitz, M. (1987), "Product Shape as a Design Innovation Strategy", Journal of Product Innovation Management, Vol. 4 No. 4, pp. 274-283.

Bhardwaj, V., Park, H. and Kim, Y.-K. (2011) "The effect of Indian consumers' life satisfaction on brand behavior toward a U.S. global brand", Journal of International Consumer Marketing, Vol. 23 No. 2, pp. 105-16.

Bhat, S. and Reddy, S.K. (1998), "Symbolic and functional positioning of brands", Journal of Consumer Marketing, Vol. 15 No. 1, pp.32-43.

Bloch, P.H. (1995), "Seeking the Ideal Form: Product Design and Consumer Response", Journal of Marketing, Vol. 59 No. 3, pp. 16-29.

Bloch, P.H. (2011), "Product Design and Marketing: Reflections After Fifteen Years", Journal of Product Innovation Management, Vol. 28 No. 3, pp. 378-80.

Boztepe, S. (2007), "User Value: Competing Theories and Models," International Journal of Design, Vol. 1 No. 2, pp. 55-63.

Cacioppo, J.T. and Petty, R.E. (1984), "The Elaboration Likelihood Model of Persuasion”, Advances in Consumer Research, Vol. 11 No. 1, pp. 673-75. 
Campbell, C. (1995), "The Sociology of Consumption", in: Miller, D. (Ed.), Acknowledging Consumption: A Review of New Studies, Routledge, London, pp. 96126.

Chitturi, R. (2009), "Emotions by design: A consumer perspective", International Journal of Design, Vol. 3 No. 2, pp. 7-17.

Clark, K.B. (1985), "The interaction of design hierarchies and market concepts in technological evolution", Research Policy, Vol. 14 No. 5, pp. 235-51.

Clarke, K. and Belk, R.W. (1978), "The effects of product involvement and task definition on anticipated consumer effort", Advances in Consumer Research, Vol. 6 No. 1, pp. 313-18.

Collins, A.M. and Loftus, E.F. (1975), "A spreading-activation theory of semantic processing", Psychological Review, Vol 82 No. 6, p. 407-28.

Cowan, N. (2001), "The magical number 4 in short-term memory: A reconsideration of mental storage capacity", Behavioral and Brain Sciences, Vol. 24 No. 1, pp. 87-185.

Creusen, M.E.H. and Schoormans, J.P.L. (2005), "The different roles of product appearance in consumer choice", Journal of Product Innovation Management, Vol. 22 No. 1, pp. 63-81.

de Pelsmacker, P., Geuens, M. and van den Bergh, J. (2006), Marketing Communications: A European Perspective, 3rd ed., Financial Times Prentice Hall.

Desmet, P. and Paul, H. (2007), "Framework of Product Experience," International Journal of Design, Vol. 1 No. 1, available at: http://www.ijdesign.org/ojs/index.php/IJDesign/article/view/66/15 [accessed on $13 / 09 / 2015]$

Eisenmann, M. (2013), "Understanding Aesthetic Innovation in the Context of Technological Evolution", Academy of Management Review, Vol. 38 No. 3, pp. 332-51.

Festinger, L. (1957), A Theory of Cognitive Dissonance, Stanford University Press, Stanford.

Gabriel, Y. and Lang, T. (1995), The Unmanageable Consumer: contemporary consumption and its fragmentation. London: Sage. 
Gros, J. (1983), Grundlagen einer Theorie der Produktsprache: Einführung [Basic Principles for a Theory of Product Language and Communication: An Introduction], Hessen State University of Art and Design Offenbach.

Herr, P.M., Sherman, S.J. and Fazio, R.H. (1983), "On the consequences of priming: Assimilation and contrast effects", Journal of Experimental Social Psychology, Vol. 19 No. 4 , p.323-40.

Hirschman, E.C. (1986), "The Effect of Verbal and Pictorial Advertising Stimuli on Aesthetic, Utilitarian and Familiarity Perceptions", Journal of Advertising, Vol. 15 No. 2, pp. 27-34.

Hirschman, E.C. and Holbrook, M.B. (1982), "Hedonic Consumption: Emerging Concepts, Methods and Propositions", Journal of Marketing, Vol. 46 No. 3, pp. 92-101.

Hoeg, J.A., Alba, J.W. and Dahl, D.W. (2010), "The good, the bad, and the ugly: Influence of aesthetics on product feature judgments“, Journal of Consumer Psychology, Vol. 20 No. 4, pp. 419-30.

Homburg, C., Schwemmle, M. and Kuehnl, C. (2015), "New Product Design: Concept, Measurement, and Consequences", Journal of Marketing, Vol. 79 No. 3, pp. 41-56.

John, D.R., Loken, B., Kim, K. and Monga, A.B. (2006), "Brand Concept Maps: A Methodology for Identifying Brand Associations Networks", Journal of Marketing Research, Vol. 43 No. 4, pp. 549-63.

Kapferer, J.-N. and Laurent, G. (1986), "Consumer Involvement Profiles: A New Practical Approach of Consumer Involvement", Journal of Advertising Research, Vol. 25 No. 6, pp. 48-56.

Keller, K.L. (1993), "Conceptualizing, Measuring, and Managing Customer-Based Brand Equity", Journal of Marketing, Vol. 57 No. 1, pp. 1-22.

Koffka, K. (1922), "Perception: An Introduction to the Gestalt-Theories", Psychological Bulletin, Vol. 19, pp. 531-85.

Kreuzbauer, R. and Malter, A. J. (2005), "Embodied cognition and new product design: Changing product form to influence brand categorization", Journal of Product Innovation Management, Vol. 22 No. 2, pp. 165-76. 
Landwehr, J.R., Labroo, A.A. and Herrmann, A. (2011), "Gut Liking for the Ordinary: Incorporating Design Fluency Improves Automobile Sales Forecasts", Marketing Science, Vol. 30 No. 3, pp. 16-29.

Landwehr, J.R., Wentzel, D. and Herrmann, A. (2012), "The Tipping Point of Design: How Product Design and Brands Interact to Affect Consumers' Preferences," Psychology and Marketing, Vol. 29 No. 6, pp. 422-33.

Landwehr, J.R., Wentzel, D. and Herrmann, A. (2013), "Product Design for the Long Run: Consumer Responses to Typical and Atypical Designs at Different Stages of Exposure“, Journal of Marketing, Vol. 77 No. 5, 92-107

Lee, D.H. (1990), "Symbolic Interactionism: Some Implications for Consumer SelfConcept and Product Symbolism Research", Advances in Consumer Research, Vol. 17 No. 1 , pp. 386-93.

Lee, M. (1995), "Effects of Schema Congruity and Involvement on Product Evaluations", Advances in Consumer Research, Vol. 22 No. 1, pp. 210-16.

Levy, S.J. (1959), "Symbols for Sale”, Harvard Business Review, Vol. 37 No. 4, pp. 117-124.

Low, G.S. and Lamb Jr., C.W. (2000), "The measurement and dimensionality of brand associations", Journal of Product and Brand Management, Vol. 9 No. 6, pp. 350-70.

Luchs, M. and Swan, K.S. (2011), "Perspective: The emergence of product design as a field of marketing inquiry", Journal of Product Innovation Management, Vol. 28 No. 3, pp. 327-45.

Lynch Jr., J.G. (2006), "Accessibility-Diagnosticity and the Multiple Pathway Anchoring and Adjustment", Journal of Consumer Research, Vol. 33 No. 1, pp. 25-27.

Lynch Jr., J.G. and Srull, T.K. (1982): "Memorial and Attentional Factors in Consumer Choice: Concepts and Research Methods", Journal of Consumer Research, Vol. 9 No. 1, pp. 18-37.

Madzharov, A.V., and Block, L.G. (2010), "Effects of product unit image on consumption of snack foods", Journal of Consumer Psychology, Vol. 20 No. 4, pp. 398409. 
Mandler, G. (1982), "The Structure of Value: Accounting for Taste", in: Clark, M. S. and Fiske, S. T. (Eds.), Affect and Cognition - The Seventeenth Annual Carnegie Symposium on Cognition, 1st ed., Erlbaum Associates, Hillsdale, NJ, pp. 3-36.

McCracken, G. (1986), "Culture and Consumption: A Theoretical Account of the Structure and Movement of the Cultural Meaning of Consumer Goods", Journal of Consumer Research, Vol. 13 No. 1, pp. 71-84.

Mervis, C.B.; Rosch, E. (1981), "Categorization of Natural Objects", Annual Review of Psychology, Vol. 32 No. 1, pp. 89-115.

Meyers-Levy, J. and Tybout, A.M. (1989), "Schema Congruity as a Basis for Product Evaluations“, Journal of Consumer Research, Vol. 16 No. 1, pp. 39-54.

Meyers-Levy, J.; Louie, T.A. and Curren, M.T. (1994), "How Does the Congruity of Brand Names Affect Evaluations of Brand Name Extensions?", Journal of Applied Psychology, Vol. 79 No. 1, pp. 46-53.

Meyvis, T. and Janiszewski, C. (2004), "When are Broader Brands stronger Brands? An Accessibility Perspective on the Success of Brand Extensions", Journal of Consumer Research, Vol. 31 No. 2, pp. 346-57.

Miller, G.A. (1956), "The Magical Number Seven, Plus or Minus Two: Some Limits on our Capacity for Processing Information”, Psychological Review, Vol. 63 No. 2, pp. 81 97.

Mitchell, A.A. and Olson, J.C. (1981), "Are product beliefs the only mediator of advertising effects on brand attitude?", Journal of Marketing Research, Vol. 18 No. 3 , pp. 318-32.

Mono, R. (1997), Design for product understanding, Liber, Stockholm.

Murdoch, P. and Flurscheim, C.H. (1983), "Form”, in: Flurscheim, C.H. (Ed.), Industrial Design in Engineering, Worcester, UK: The Design Council, pp. 105-31.

Noble, C.H. and Kumar, M. (2010), Exploring the Appeal of Product Design: A Grounded, Value-Based Model of Key Design Elements and Relationships", Journal of Product Innovation Management, Vol. 27 No. 5, pp. 640-57.

O'Cass, A., and Frost, H. (2002), "Status brands: examining the effects of non-productrelated brand associations on status and conspicuous consumption", Journal of Product and Brand Management, Vol. 11 No. 2, pp. 67-88 
Orth, U.R. and Malkewitz, K. (2008), "Holistic Package Design and Consumer Brand Impressions," Journal of Marketing, Vol. 72 No. 3, pp. 64-81.

Osgood, C.E., Suci, G.J. and Tannenbaum, P.H. (1957), The Measurement of Meaning, Urbana, II: University of Illinois Press.

Park, C.W., Jaworski, B.J. and Maclnnis, D.J. (1986), "Strategic brand concept image management", Journal of Marketing, Vol. 50 No. 4, pp. 135-45.

Petty, R.E., Cacioppo, J.T. and Schumann, D. (1983), "Central and Peripheral Routes to Advertising Effectiveness: The Moderating Role of Involvement", Journal of Consumer Research, Vol. 10 No. 2, S. 135-46.

Pieters, R. and Warlop, L. (1999), "Visual attention during brand choice: The impact of time pressure and task motivation", International Journal of Research in Marketing, Vol. 16 No. 1, pp. 1-17.

Pohl, R.F. and Eisenhauer, M. (1997), "SARA: An associative model for anchoring and hindsight bias", in: Shafto, M.G. and Langley, P. (Eds.), Proceedings of the Nineteenth Annual Conference of the Cognitive Science Society, Lawrence Erlbaum Associates Inc., Mahwah, NJ, p. 1103.

Pohl, R.F.; Hardt, O. and Eisenhauer, M. (2000), "SARA Ein kogntitives Prozeßmodell zur Erklärung von Ankereffekt und Rückschaufehler" [SARA - A cogntitive process model to explain anchoring effect and hindsight bias], Kognitionswissenschaft, Vol. 9 No. 2, pp. 77-92.

Pohl, R.F., Eisenhauer, M. and Hardt, O. (2003), "SARA: A cognitive process model to stimulate the anchoring effect and hindsight bias", Memory, Vol. 11 No. 4/5, 337-56.

Raaijmakers, J.G.W. and Shiffrin, R.M. (1980), "SAM: A theory of probabilistic search of associative memory", in: Bower, G.H. (Ed.), The psychology of learning and motivation, Vol. 14, San Diego, CA: Academic Press, pp. 207-62.

Rafaeli, A. and Vilnai-Yavetz, I. (2004), "Emotion as a Connection of Physical Artifacts and Organizations", Organization Science, Vol. 15 No. 6, pp. 671-86.

Raghubir, P., and Greenleaf, E. (2006), "Ratios in proportion: What should the shape of the package be?", Journal of Marketing, Vol. 70 No. 2, pp. 95-107. 
Ravasi, D. and Stigliani, I. (2012), "Product Design: A Review and Research Agenda for Management Studies", International Journal of Management Reviews, Vol. 14 No. 4, pp. 464-88.

Rettie, R. and Brewer, C. (2000), "The Verbal and Visual Components of Package Design", Journal of Product and Brand Management, Vol. 9 No. 1, pp. 56-70.

Rosch, E. (1975), "Cognitive Representations of Semantic Categories“, Journal of Experimental Psychology: General, Vol. 104 No. 3, pp. 192-233.

Sassatelli, R. (2007), Consumer Culture: History, Theory and Politics. London: Sage.

Schlenker, B. R. and Leary, M. R. (1985), "Social Anxiety and Communication about the Self", Journal of Language and Social Psychology, Vol. 4 No. 3/4, pp. 171-192.

Schlenker, B. R. and Weigold, M. F. (1989), "Goals and the Self-Identification Process", in: Pervin, L. A. (Eds.): Goal Concepts in Personality and Social Psychology, New York: Hillsdale, NJ: Erlbaum.

Schlenker, B. R. and Weigold, M. F. (1992), "Interpersonal process involving impression regulation and management", Annual Review of Psychology, Vol. 43 No. 1, pp. $133-68$.

Schmitt, B.H. and Simonson, A. (1997), Marketing Aesthetics: The Strategic Management of Brands, Identity, and Image, New York: The Free Press.

Shiffrin, R.M. and Raaijmakers, J.G.W. (1992), "The SAM retrieval model: A retrospective and a prospective, in: Healy, A.F., Kosslyn, S.M. and Shiffrin, R.M. (Eds.), From learning processes to cognitive processes: Essays in Honor of William K. Estes, Vol. 2, Lawrence Erlbaum Associates Inc., Hillsdale, NJ, pp. 69-86.

Simmel, G. (1957), "Fashion”, American Journal of Sociology, Vol. 62 No. 2, pp. 541-58. Sirgy, M.J. (1982), "Self-Concept in Consumer Behavior: A Critical Review", Journal of Consumer Research, Vol. 9 No. 3, pp. 287-300.

Strack, F. and Mussweiler, T. (1997): „Explaining the Enigmatic Anchoring Effect: Mechanism of Selective Accessibility", Journal of Personality and Social Psychology, Vol 73, No. 3, p. 437-46.

Townsend, C., and Shu, S.B. (2010), "When and how aesthetics influences financial decisions", Journal of Consumer Psychology, Vol. 20 No. 4, pp. 452-58. 
Van Rompay, T.J.L., Pruyn, A.T.H. and Tieke, P. (2009), “Symbolic meaning integration in design and its influence on product and brand evaluation, International Journal of Design, Vol. 3 No. 2, pp. 19-26.

Yamamoto, M. and Lambert, D.R. (1994), "The impact of product aesthetics on the evaluation of industrial products", Journal of Product Innovation Management, Vol. 11 No. 4, pp. 309-24.

Veblen, T. (1899/1953), The Theory of the Leisure Class: An Economic Study of Institutions, Allen and Unwin, London.

Veryzer, R.W. (1993), "Aesthetic Response and the Influence of Design Principles on Product Preferences", Advances in Consumer Research, Vol. 20 No. 1, pp. 224-28.

Wertheimer, M. (1925), Drei Abhandlungen zur Gestalttheorie [Three Reflections on Gestalt theory], Verlag der Philosophischen Akademie, Erlangen.

Wyer, R. S. and Srull, T. K. (1986), "Human Cognition in Its Social Context," Psychological Review, Vol. 93 No. 3, pp. 322-59. 


\section{Appendices}

\begin{tabular}{|l|l|}
\hline \multicolumn{2}{|c|}{ Preliminary studies and main study } \\
\hline $\begin{array}{l}\text { Preliminary study } 1 \\
(\mathrm{~N}=150)\end{array}$ & $\begin{array}{l}\text { Selection of two low- and two high-involvement product } \\
\text { categories }\end{array}$ \\
\hline $\begin{array}{l}\text { Preliminary study } 2 \\
(\mathrm{~N}=120)\end{array}$ & $\begin{array}{l}\text { Selection of one strong and one weak brand for each of the } \\
\text { product categories }\end{array}$ \\
\hline $\begin{array}{l}\text { Preliminary study } 3 \\
(\mathrm{~N}=30)\end{array}$ & Development of scales for measuring the associations \\
\hline \begin{tabular}{l} 
Professional development of product designs with specific symbolic designs \\
\hline $\begin{array}{l}\text { Preliminary study } 4 \\
(\mathrm{~N}=120)\end{array}$
\end{tabular} & $\begin{array}{l}\text { Manipulation check of the stimuli products on their symbolic } \\
\text { designs }\end{array}$ \\
\hline $\begin{array}{l}\text { Preliminary study } 5 \\
(\mathrm{~N}=120)\end{array}$ & $\begin{array}{l}\text { Manipulation check of the stimuli products on their congruence } \\
\text { with the product category }\end{array}$ \\
\hline Main study (n=490) & Measurement of the influences of the stimuli associations \\
\hline
\end{tabular}

Appendix 1. Preliminary studies and main study

\section{Associations scale}

The associations scale contained the following adjective pairs (similar as a semantic differential scale, Osgood et al., 1957):

\section{- Feminine association items:} rough/gentle, hard/soft, angular/round and masculine/feminine.

- Noble association items: ordinary/exclusive, primitive/elevated, cheap/expensive and common/noble.

- Further items:

unprofessional/professional, dishonest/honest, undynamic/dynamic, uncharismatic/charismatic, incompetent/competent, distorted/undistorted, not chic/chic, not classy/classy, unimaginative/imaginative, not fresh/fresh, artificial/natural, not catchy/catchy and unsuccessful/successful.

Appendix 2. Associations scale 

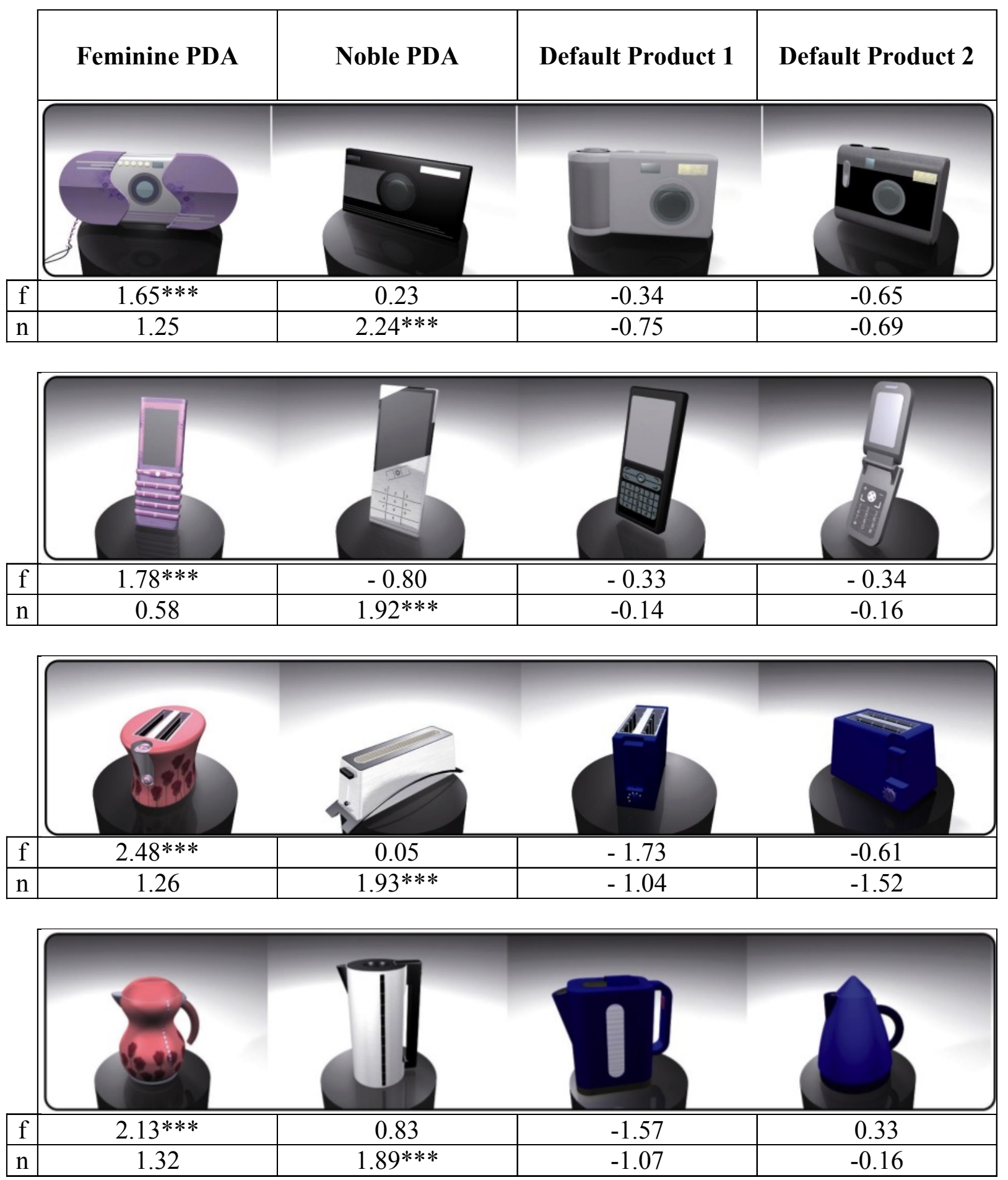

$\mathrm{f}$ : feminine association scale

n: noble association scale

$\mathrm{N}=120$ (For each product category: $\mathrm{N}=30$ ), Cronbach's $\alpha>, 7$

$* * *=p<.001$ (Significance of differences between designed products and default products)

Appendix 3: Stimuli with symbolic design evaluations 


\begin{tabular}{|c|c|c|c|c|c|c|c|}
\hline \multicolumn{2}{|c|}{ Congruent Associations (Symbolic design: Noble) } \\
\hline $\begin{array}{c}\text { Product } \\
\text { Category }\end{array}$ & Brand & $\begin{array}{c}\text { Brand } \\
\text { Association } \\
\text { pre I }\end{array}$ & $\begin{array}{c}\text { Symbolic } \\
\text { Design II }\end{array}$ & $\begin{array}{c}\text { Brand } \\
\text { Association } \\
\text { post III }\end{array}$ & $\begin{array}{c}\text { Global } \\
\text { distance 1 } \\
\text { I-III }\end{array}$ & $\begin{array}{c}\text { Global } \\
\text { distance 2 } \\
\text { II-III }\end{array}$ & $\begin{array}{c}\text { Global } \\
\text { distance } \\
\mathbf{3} \\
\text { I-II }\end{array}$ \\
\hline $\begin{array}{c}\text { Digital } \\
\text { Cameras }\end{array}$ & strong & $0.98(0.85)$ & $1.22(0.99)$ & $1.22(0.84)$ & 0.57 & 0.41 & 0.51 \\
\cline { 2 - 9 } & weak & $0.29(0.97)$ & $1.63(1.06)$ & $1.51(1.00)$ & 2.53 & 0.36 & 2.84 \\
\hline $\begin{array}{c}\text { Mobile } \\
\text { Phones }\end{array}$ & strong & $0.62(1.12)$ & $1.57(1.11)$ & $1.38(1.02)$ & 1.63 & 0.44 & 1.95 \\
\cline { 2 - 9 } Toasters & weak & $-0.76(1.15)$ & $1.66(1.10)$ & $1.15(1.24)$ & 3.86 & 1.10 & 4.95 \\
\cline { 2 - 9 } & strong & $0.72(0.95)$ & $1.13(1.14)$ & $1.19(0.95)$ & 1.08 & 0.26 & 1.06 \\
\hline \multirow{2}{*}{ Kettles } & strong & $0.47(0.76)$ & $1.76(1.03)$ & $0.93(0.94)$ & 0.60 & 0.59 & 0.85 \\
\cline { 2 - 9 } & weak & $-0.06(0.87)$ & $1.42(1.06)$ & $1.68(0.82)$ & 3.54 & 0.28 & 3.68 \\
\hline
\end{tabular}

\begin{tabular}{|c|c|c|c|c|c|c|c|}
\hline \multicolumn{2}{|c|}{ Incongruent Associations (Symbolic Design: Feminine) } \\
\hline \multirow{2}{*}{$\begin{array}{c}\text { Product } \\
\text { category }\end{array}$} & Brand & $\begin{array}{c}\text { Brand } \\
\text { association } \\
\text { pre I }\end{array}$ & $\begin{array}{c}\text { Symbolic } \\
\text { Design II }\end{array}$ & $\begin{array}{c}\text { Brand } \\
\text { association } \\
\text { post III }\end{array}$ & $\begin{array}{c}\text { Global } \\
\text { distance 1 } \\
\text { I-III }\end{array}$ & $\begin{array}{c}\text { Global } \\
\text { distance 2 } \\
\text { II-III }\end{array}$ & $\begin{array}{c}\text { Global } \\
\text { distance } \\
\mathbf{3} \\
\text { I-II }\end{array}$ \\
\hline \multirow{2}{*}{$\begin{array}{c}\text { Digital } \\
\text { cameras }\end{array}$} & strong & $-0.34(0.77)$ & $1.56(1.25)$ & $1.63(1.10)$ & 4.00 & 0.37 & 3.84 \\
\cline { 2 - 9 } $\begin{array}{c}\text { Mobiles } \\
\text { phones }\end{array}$ & strong & $-0.16(0.91)$ & $0.75(1.12)$ & $0.51(0.95)$ & 1.53 & 1.12 & 2.28 \\
\cline { 2 - 9 } & weak & $-0.27(0.80)$ & $0.83(1.33)$ & $0.91(1.28)$ & 2.48 & 0.49 & 2.44 \\
\hline \multirow{2}{*}{\begin{tabular}{c} 
Toasters \\
\cline { 2 - 9 }
\end{tabular}} & strong & $-0.31(0.87)$ & $2.12(0.84)$ & $1.56(1.01)$ & 4.09 & 1.31 & 5.22 \\
\cline { 2 - 9 } Kettles & weak & $-0.32(1.03)$ & $1.34(1.20)$ & $1.11(1.43)$ & 2.95 & 0.65 & 3.50 \\
\cline { 2 - 9 } & strong & $-0.32(0.84)$ & $2.48(0.58)$ & $1.73(1.16)$ & 4.16 & 1.54 & 5.65 \\
\hline
\end{tabular}

Appendix 4: Results of the main experiment 